\title{
PERBAIKAN TATA LETAK PENYIMPANAN BARANG DI GUDANG UNTUK REDUKSI JARAK TEMPUH PERJALANAN MATERIAL HANDLING
}

\author{
WINANDA KARTIKA ${ }^{1}$, AHMAD WIMBO HELVIANTO ${ }^{2}$ \\ Program Studi Manajemen Logistik Industri Elektronika Politeknik APP Jakarta \\ E-mail: winanda-kartika@kemenperin.go.id ${ }^{1}$
}

DOI Number : $\underline{10.30988 / \text { imil.v111.10 }}$

\begin{abstract}
Warehouse acts as distributor of the product to the consumer. This is done by PT.XYZ as warehouse outsourcing. PT. XYZ manage a number of beverage products manufactured by PT ABC. The problem faced is the warehouse has not had an arrangement regarding the layout of product placement so that the preparation is done randomly depending on the overall storage blocks are empty. Each block storage in this warehouse holds only one type of product and the expiration date, so that the placement of the goods must be in blocks that are empty and do not take into account travel distance of material handling in the store and pick up the goods. In addition, the product storage memory depends only on the operator alone. Therefore, it is necessary to redesign the product placement on the storage location of the performance criteria minimize the total travel distance of material handling. Proposed layout product placement implementing dedicated storage method is a method for solving the layout of the warehouse includes product placement in the warehouse based on the amount of activity out of the product in the warehouse with the shortest distance to I/O point. With the application of this method, it is expected the product to be stored occupies a fixed location to enable the operator to store and retrieve the product. Results from a dedicated application, obtained the total travel distance by $23719.36 \mathrm{~m}$, while the total mileage of the existing condition of 27038.1 with the percentage of $12.27 \%$ decline
\end{abstract}

Keywords: dedicated storage, layout of product placement, space requirement, throughput

\begin{abstract}
Abstrak
Gudang berperan sebagai distributor untuk menyalurkan produk menuju konsumen. Hal inilah yang dilakukan oleh PT.XYZ selaku warehouse outsourcing. PT XYZ mengelola sejumlah produk minuman yang diproduksi oleh suatu perusahaan multiinternasional PT ABC. Permasalahan yang dihadapi adalah gudang belum memiliki pengaturan mengenai tata letak penempatan produk sehingga penyusunan dilakukan secara acak tergantung blok penyimpanan yang kosong keseluruhan. Setiap blok penyimpanan di gudang ini hanya menampung satu jenis produk dan satu tanggal kadaluarsa, sehingga penempatan barang harus di blok yang kosong dan tidak memperhitungkan jarak tempuh perjalanan material handling dalam menyimpan dan mengambil barang. Selain itu, penyimpanan produk hanya bergantung pada daya ingat operator saja. Oleh karena itu, perlu dilakukan penataan ulang penempatan produk pada lokasi penyimpanan dengan kriteria performansi meminimasi total jarak tempuh perjalanan material handling. Usulan tata letak penempatan produk menerapkan metode dedicated storage yaitu suatu metode untuk penyelesaian masalah tata letak gudang mencakup penempatan produk di gudang berdasarkan banyaknya aktivitas keluar masuk produk di gudang dengan jarak tempuh terpendek terhadap pintu I/O. Dengan adanya penerapan metode ini, diharapkan
\end{abstract}


produk yang akan disimpan menempati lokasi yang tetap untuk memudahkan operator dalam menyimpan dan mengambil produk. Hasil dari penerapan dedicated, diperoleh total jarak tempuh perjalanan sebesar 23719,36 m, sedangkan pada kondisi eksisting total jarak tempuh sebesar 27038,1 dengan persentase penurunan $12,27 \%$.

Kata kunci: dedicated storage, tata letak penempatan barang, space requirement, throughput.

\section{PENDAHULUAN}

Gudang merupakan salah satu aspek penting yang dimiliki oleh perusahaan. Penataan gudang yang baik akan berpengaruh pada penghematan biaya operasional gudang dalam hal ini adalah biaya penyimpanan dan biaya material handling. Oleh karena itu, gudang harus dirancang agar material atau barang dapat mengisi kapasitas ruang secara maksimal baik secara vertikal maupun horizontal. Untuk mengelola gudang dengan baik perlu adanya sistem yang dapat dibangun dan dikendalikan dengan baik. Sistem pergudangan yang baik adalah sistem pergudangan yang mampu memanfaatkan ruang untuk penyimpanan secara efektif agar dapat meningkatkan utilisasi ruang serta meminimalisasi jarak atau biaya material handling (Heragu, 2007:11.1-11.6).

Dalam perusahaan manufaktur maupun jasa, perusahaan besar maupun perusahaan kecil sering dijumpai permasalahan pada pengaturan tata letak produk jadi. Permasalahan tata letak gudang yang dijadikan penelitian saat ini adalah gudang PT.XYZ yang menyelenggarakan jasa pergudangan/ outsourcing warehouse. Gudang PT $\mathrm{XYZ}$ menempati area gudang seluas sekitar $\pm 1.500 \mathrm{~m}^{2}$ yang dibagi menjadi dua bagian yaitu zona A dan zona B. Barang-barang yang ditangani oleh gudang ini adalah produk minuman yaitu Mizone, Aqua dan Vit Levite. Pada saat diterima, produk sudah disusun diatas pallet kemudian pallet digunakan sebagai media penyimpanan. Desain area penyimpanan di gudang PT XYZ terdiri dari blok-blok penyimpanan dengan lebar 1,5 m. Area penyimpanan zona A terdiri 31 blok dan zona B terdiri dari 24 blok yang tersusun secara vertikal. Antara zona A dan zona B dipisahkan oleh jalur lintasan/ gang untuk pergerakan material handling dengan jarak 4,5 m., sedangkan antar blok tidak ada gang sehingga penyimpanan dan pengambilan produk hanya dilakukan dari depan ke belakang menggunakan forklift. Pengambilan produk di gudang ini menggunakan sistem FIFO sehingga satu blok hanya boleh terisi oleh produk yang sejenis dan tanggal kadaluarsa yang sama. Penempatan produk tidak memperhatikan jarak tempuh perjalanan alat materia handling karena penempatan blok berdasarkan blok yang kosong saja..

Berdasarkan permasalahan riil gudang PT XYZ, penelitian ini mencoba melakukan perbaikan tata letak gudang dengan menata ulang penempatan produk untuk meminimasi jarak tempuh perjalanan forklift. Adapun faktor yang menjadi pertimbangan dalam meminimasi jarak tempuh perjalanan forklift adalah rata-rata penerimaan produk dan rata-rata pengambilan produk per periode serta kapasitas blok. Tujuan dari penelitian ini adalah memberikan usulan perbaikan tata letak penempatan barang untuk meminimasi jarak tempuh perjalanan forklift. Ruang lingkup penelitian ini memiliki batasan-batasan 
pembahasan yaitu pengamatan hanya dilakukan pada gudang PT XYZ, tidak ada perhitungan biaya, dan setiap blok yang digunakan hanya menampung satu jenis produk dengan tanggal kadaluarsa yang sama.

\section{METODE PENELITIAN Identifikasi Permasalahan}

Tahapan penelitian diawali dengan mengidentifikasi permasalahan yang dihadapi yaitu penempatan produk secara acak sehingga tidak memperhitungkan jarak tempuh perjalanan forklift sebagai alat material handling. Pendekatan yang digunakan adalah pengaturan barang berdasarkan metode dedicated storage, barang disusun berdasarkan jumlah aktivitas/blok terbesar kemudian ditempatkan pada blok yang mempunyai jarak tempuh terkecil. Rata-rata penerimaan dan pengiriman produk, kebutuhan ruang dan kapasitas angkut material handling menjadi faktor penentu penerapan metode ini. Dalam memberikan usulan perbaikan tata letak penempatan barang di gudang untuk meminimasi jarak tempuh perjalanan material handling, penelitian yang digunakan sebagai acuan adalah penelitian Permana (2014).

\section{Penentuan Tujuan Penelitian}

Tujuan penelitian dari permasalahan diatas adalah memberikan usulan perbaikan tata letak penyimpanan barang untuk mereduksi jarak tempuh perjalanan material handling.

\section{Pengumpulan Data}

Pengumpulan data pada proses penelitian dilakukan dengan metode wawancara, pengamatan langsung, dan pengumpulan data-data sekunder.

\section{Pembahasan dan Analisis}

Pembahasan merupakan penerapan metode dedicated storage dalam penyelesaian persoalan tata letak penempatan produk untuk meminimalisasi jarak tempuh perjalanan material handling.

Dalam penyelesaian permasalahan ini, dilakukan beberapa tahap perhitungan yaitu Space Requirement, Throughput, Jarak Tempuh Perjalanan Material Handling setiap produk dari dan ke I/O point.

1. Space Requiremet adalah menghitung kebutuhan ruang untuk penyimpanan setiap jenis produk. Perhitungan berdasarkan rata-rata penerimaan produk dibagi kapasitas tempat penyimpanan.

2. Throughput adalah jumlah aktivitas penyimpanan dan pengambilan produk yang dilakukan oleh material handling.

3. Perhitungan jarak tempuh perjalanan material handling dari dan ke I/O point menggunakan rumus rectilinier distance.

\section{Pengurangan Jarak Tempuh Perjalanan Material Handling}

Pada tahap ini, dilakukan penempatan produk berdasarkan nilai throughpu terhadap sapace requirement $(\mathrm{T} / \mathrm{S})$ terbesar pada tempat penyimpanan yang mempunyai jarak terdekat. Penempatan dilakukan untuk semua jenis produk. Untuk lebih jelas penyelesaian persoalan tata letak 
penempatan produk dengan menggunakan metode dedicated storage dapat dilihat pada Gambar 1 berikut:

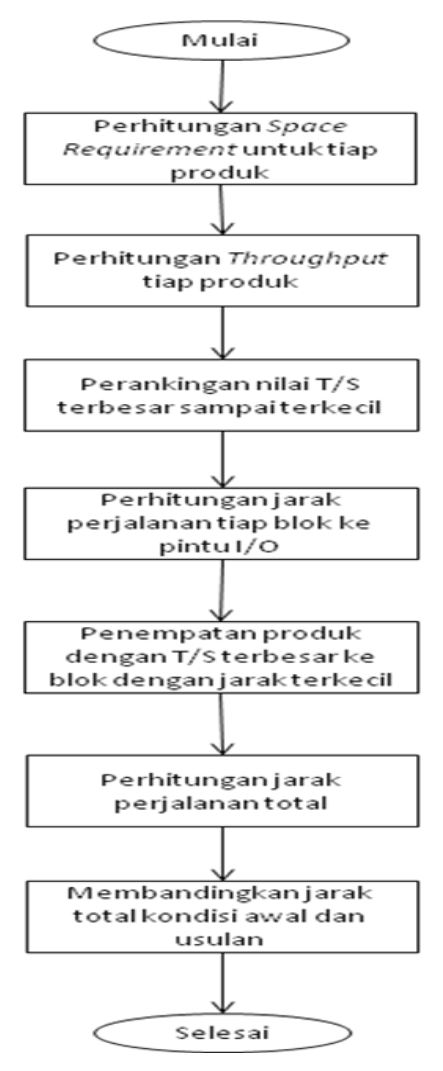

Gambar 1. Tahapan Peneyelesaian Tata Letak Penempatan Produk

\section{HASIL DAN PEMBAHASAN Deskripsi Gudang}

Gudang PTXYZ merupakan gudang outsourcing dengan memiliki luas \pm $1500 \mathrm{~m}^{2}$. Penyimpanan produk di gudang ini menggunakan pallet yang berukuran $120 \mathrm{~cm} \times 100 \mathrm{~cm} \times 18 \mathrm{~cm}$ dengan daya tampung sekitar 84 box minuman. Setelah produk disusun diatas pallet kemudian pallet diletakkan di area penyimpanan yaitu berupa blok penyimpanan. Ada dua area penyimpanan yang disebut dengan zona yaitu zona A dan zona B. Zona A dapat menyimpan 11 susun pallet dengan 3 tumpukan keatas, sedangkan zona B dapat menyimpan 7 susun pallet dengan 3 tumpukan keatas. Lebar setiap blok sekitar 1,5 $\mathrm{m}$.

Karena pengambilan barang menggunakan sistem FIFO, maka satu blok hanya boleh disimpan untuk satu jenis produk, ukuran, karakteristik seperti tanggal kadaluarsa. Akibat dari sistem penyimpanan seperti itu, blok baru dapat digunakan lagi sebagai tempat penyimpanan jika sudah tidak ada barang yang tersisa di blok tersebut atau kosong. Salah satu kelemahan gudang ini adalah barang yang masuk langsung disimpan diarea yang kosong saja dan tidak ada penempatan produk yang jelas kemudian baru dimasukan ke dalan sistem sehingga tidak memperhatikan jarak tempuh perjalanan atau material handling. Penyimpanan dan pengambilan barang hanya menggunakan forklift. Gudang ini memiliki dua pintu yaitu satu pintu masuk dan satu pintu keluar yang posisinya sejajar. Layout eksisting gudang PT XYZ dapat dilihat pada Gambar 2.

\section{Data Jenis Produk}

Produk yang disimpan di gudang dalam bentuk botolan yang dimasukan ke dalam kardus/box. Jumlah produk yang disimpan dalam gudang ada tiga jenis produk denngan bermacam-macam ukuran dan rasa yaitu Aqua, Mizone, dan Levite. Data Produk dapat dilihat pada Tabel 1.

\section{Data Penerimaan dan Pengiriman Tiap Produk}

Aktivitas yang terjadi di gudang meliputi proses penerimaan, penyimpanan dan pengiriman produk. 
Data penerimaan adalah data dari jumlah produk yang masuk ke gudang dalam bentuk box yang kemudian ditempatkan diatas pallet. Data pengiriman adalah data produk harian yang keluar dari gudang penyimpanan untuk dikirim ke konsumen. Data yang diperoleh

Tabel 1.Jenis Produk yang Disimpan di Gudang PT XYZ

\begin{tabular}{|c|c|c|c|c|c|c|c|}
\hline \multicolumn{4}{|c|}{ di Gudang PT XYZ } & $\mathrm{N}$ & \multirow{3}{*}{$\begin{array}{l}\text { Kode } \\
\text { Produ } \\
\text { k }\end{array}$} & \multirow{3}{*}{$\begin{array}{l}\text { Rata-Rata } \\
\text { Penerima } \\
\text { an Produk }\end{array}$} & \multirow[b]{2}{*}{$\begin{array}{l}\text { Rata- } \\
\text { Rata } \\
\text { Pengirim } \\
\text { an }\end{array}$} \\
\hline $\begin{array}{l}N \\
0\end{array}$ & $\begin{array}{l}\text { Kode } \\
\text { Produ } \\
\text { k }\end{array}$ & Nama Produk & Ukuran & $\begin{array}{l}\text { Isißbo } \\
\mathrm{x}\end{array}$ & & & \\
\hline \multirow[t]{2}{*}{1.} & 7456 & Mizone Orange Lime & $500 \mathrm{ml}$ & 12 & & & Produk \\
\hline & 8 & & & 1. & 7454 & & \\
\hline \multirow[t]{2}{*}{2.} & 7459 & Mizone Apple Guava & $500 \mathrm{ml}$ & 12 & 8 & 216 & 198 \\
\hline & 3 & & & 2. & 7455 & & \\
\hline \multirow[t]{2}{*}{3.} & 7456 & Mizone Lychee Lemon & $500 \mathrm{ml}$ & 12 & 3 & 140 & 116 \\
\hline & 7 & & & 3. & 7456 & & \\
\hline \multirow[t]{2}{*}{4.} & 8762 & Levite Rasa Jeruk & $350 \mathrm{ml}$ & 12 & 1 & 180 & 165 \\
\hline & 4 & & & 4. & 7456 & & \\
\hline \multirow[t]{2}{*}{5 . } & 8762 & Levite Rasa Jambu Biji & $350 \mathrm{ml}$ & 12 & 7 & 63027 & 62807 \\
\hline & 6 & & & 5. & 7456 & & \\
\hline \multirow[t]{2}{*}{6.} & 8743 & Mizone Fresh in Crispy & $500 \mathrm{ml}$ & 12 & 8 & 21033 & 20970 \\
\hline & 6 & Apple & & 6. & 7459 & & \\
\hline \multirow[t]{2}{*}{7.} & 8762 & Mizone Fresh in JC Straw & $500 \mathrm{ml}$ & 12 & 3 & 6881 & 6755 \\
\hline & 5 & & & 7. & 8743 & & \\
\hline \multirow[t]{2}{*}{8.} & 7455 & Aqua & 1500 & 12 & 6 & 2877 & 2783 \\
\hline & 3 & & $\mathrm{ml}$ & 8. & 8762 & & \\
\hline \multirow[t]{2}{*}{9.} & 7454 & Aqua & $240 \mathrm{ml}$ & $4 \underline{8}$ & 4 & 4535 & 4441 \\
\hline & 8 & & & 9. & 8762 & & \\
\hline \multirow{3}{*}{$\begin{array}{l}10 \\
.\end{array}$} & 7456 & Aqua & $600 \mathrm{ml}$ & 24 & 5 & 1964 & 1932 \\
\hline & 1 & & & 10 & 8762 & & \\
\hline & & & & & 6 & 210 & 179 \\
\hline
\end{tabular}

adalah data rata-rata penerimaan dan pengiriman produk jadi selama 8 bulan, terhitung dari bulan Januari 2015 sampai dengan Agustus 2015. Data tersebut dapat dilihat pada Tabel 2.

Tabel 2. Data Rata-Rata Penerimaan dan Pengiriman Produk Minuman N Kode Rata-Rata Rata- 
tempat spesifik untuk menyimpan produk. Produk yang masuk akan disimpan pada blok yang kosong dan selama blok tersebut masih terisi maka tidak boleh ada penyimpanan di blok tersebut.

Lokasi penyimpanan digambarkan dalam bentuk Area Template yang memiliki 55 blok. Dalam satu blok di zona A , bisa menyimpan 11 susun pallet dengan 3 tumpukan ke atas, sedangkan di zona B, satu blok hanya bisa menyimpan 7 susun pallet dengan 3 tumpukan ke atas. Layout penyimpanan produk di gudang dapat dilihat pada Gambar 2.

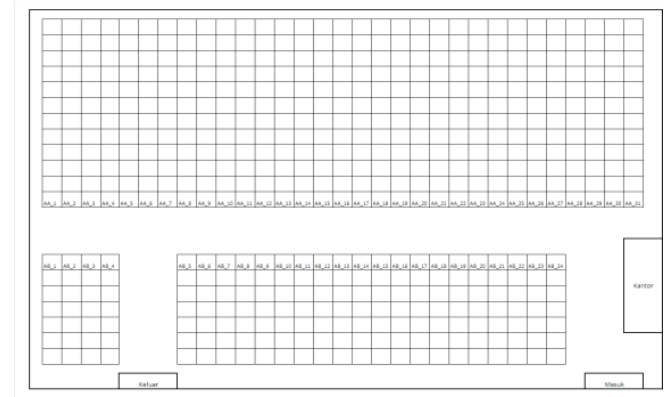

Gambar 2. Layout Gudang Eksisting

\section{Pengolahan Data}

Data-data yang diperoleh kemudian diolah untuk mendapatkan penyelesaian persoalan tata letak gudang terutama penentuan lokasi penyimpan barang di gudang. Persoalan ini diselesaikan untuk mendapatkan lokasi penyimpanan barang yang tepat sehingga mengurangi jarak dan waktu proses

Tabel 3. Kebutuhan Ruang Tiap Produk

\begin{tabular}{llllll}
\hline & Ko & Ju & Rat & Kap & $\begin{array}{l}\text { Spac } \\
\text { de }\end{array}$ \\
N & mla & a- & asita & eRe \\
o & Pro & h & Rat & S & $q$ \\
& du & box & a & Blok & (Blo \\
& k & per & Ter & & k) \\
\hline
\end{tabular}

pada saat picking. Metode yang digunakan adalah dedicated storage dimana produk yang disimpan di tempatkan pada lokasi yang spesifik dan hanya satu jenis produk yang ditempatkan pada lokasi tersebut. Adapun tahapan metode dedicated storage adalah sebagai berikut:

\section{Space Requirement (Kebutuhan Ruang)}

Tahapan penentuan kebutuhan ruang bertujuan untuk menentukan kapasitas blok untuk menampung produk sesuai dengan persyaratan penyimpanan barang. Pada perusahaan PT. XYZ, produk sejenis yang sudah dimasukkan dalam kardus/box disusun diatas pallet. Pallet sekaligus dipakai sebagai tempat penyimpanan di gudang dengan kapasitas satu pallet berbedabeda tergantung jenis produk. Seperti yang sudah dijelaskan, kapasitas blok di gudang ini berbeda yaitu zona A, satu blok terdiri dari 11 susun, sedangkan untuk zona B, satu blok terdiri dari 11 susun. Satu susun terdiri dari 3 pallet ditumpuk ke atas. Misal, satu blok dapat menampung 7 susun dimana 1 susun terdiri 3 pallet ditumpuk ke atas maka dalam blok ini dapat menampung sebanyak ( $7 \times 3$ ) pallet. Kebutuhan ruang atau blok untuk tiap jenis produk dapat dilihat pada Tabel 3.

$$
\begin{array}{ll}
\text { pall im } \\
\text { et }
\end{array}
$$

\begin{tabular}{llllll}
\hline \multicolumn{7}{c}{ Zona A } & & & \\
\hline 1 & 745 & 48 & 216 & 1584 & 1 \\
& 48 & & & & \\
\hline 2 & 745 & 65 & 140 & 2145 & 1 \\
& 53 & & & & \\
\hline
\end{tabular}




\begin{tabular}{llllll}
\hline 3 & 745 & 40 & 180 & 1320 & 1 \\
& 61 & & & & \\
\hline 4 & 745 & 84 & 206 & 2772 & 8 \\
& 67 & & 91 & & \\
\hline 5 & 745 & 84 & 210 & 2772 & 8 \\
& 68 & & 33 & & \\
\hline 6 & 745 & 84 & 688 & 2772 & 3 \\
& 93 & & 1 & & \\
\hline 7 & 874 & 84 & 287 & 2772 & 2 \\
& 36 & & 7 & & \\
\hline
\end{tabular}

Contoh perhitungan kapasitas blok untuk produk dengan kode 74548 :

Rata-rata penerimaan produk 74548 adalah 216 buah.Dalam satu pallet maksimal menampung 84 buah dan dalam tiap blok AA dapat menampung 21 pallet dengan 7 susun ke belakang dan 3 tumpukan ke atas, maka space requirement untuk produk ini adalah:

$$
\begin{aligned}
& S=\frac{216}{7 \times 3 \times 84} \\
& =0.1363636 \sim 1 \text { Blok }
\end{aligned}
$$

Dalam suatu zona penyimpanan, gudang ini tidak memiliki aisle dari satu ke blok lainnya maka untuk memudahkan dalam pengambilan produk, dalam satu blok hanya dapat digunakan untuk satu jenis produk saja.

\section{Perhitungan Throughput}

Tabel 4 Throughput Tiap Jenis

\begin{tabular}{|c|c|c|c|c|c|c|}
\hline \multicolumn{7}{|c|}{ Zona A } \\
\hline \multirow{4}{*}{$\begin{array}{ll}\mathrm{N} \\
\mathrm{o} \\
\mathrm{o} \\
\mathrm{ed}\end{array}$} & Rat & Rat & Box & $T$ & $T$ & \\
\hline & $a^{-}$ & $a^{-}$ & yang & $\mathrm{Te}$ & $\mathrm{Ki}$ & $\mathrm{T}$ \\
\hline & Ter & $\mathrm{Kir}$ & dian & ri & ri & ot \\
\hline & ima & im & gkut & $\mathrm{ma}$ & $\mathrm{m}$ & \\
\hline
\end{tabular}
Produk Zona A

\begin{tabular}{llllll}
\hline 8 & 876 & 125 & 453 & 4125 & 2 \\
& 24 & & 5 & & \\
\hline 9 & 876 & 84 & 196 & 2772 & 1 \\
& 25 & & 4 & & \\
\hline 1 & 876 & 125 & 210 & 4125 & 1 \\
0 & 26 & & & & \\
\hline Zona B & & & & \\
\hline 1 & 745 & 84 & 423 & 1764 & 24 \\
1 & 67 & & 36 & & \\
\hline
\end{tabular}

Throughput digunakan sebagai ukuran jumlah aktivitas penyimpanan/ pengambilan yang terjadi per periode waktu. Jadi perhitungan didasarkan pada pengukuran aktivitas penerimaan dan pengiriman dalam gudang. Aktivitas penerimaan dan pengiriman menggunakan forklift, setiap forklift memiliki kapasitas angkut 3 pallet dimana setiap pallet mempunyai beban 84 box. Hal ini merupakan batas maksimal yang diperbolehkan dalam proses pemindahan produk. Oleh karena itu, untuk menentukan banyaknya produk yang dapat diangkut dapat dihitung dari banyaknya produk. Misal untuk produk dengan kode 74548 diketahui bahwa satu pallet dapat menampung 48 box Mizone maka untuk sekali pengangkutan forklift hanya dapat membawa 3 pallet yang berisi 144 box. Perhitungan Throughput untuk tiap jenis produk dapat dilihat pada Tabel 4 dan Tabel 5.

\begin{tabular}{llllllll}
\hline & 74 & & & & & & \\
& 54 & & & & & & \\
1 & 8 & 216 & 198 & 144 & 2 & 2 & 4 \\
\hline & 74 & & & & & & \\
& 55 & & & & & & \\
2 & 3 & 140 & 116 & 195 & 1 & 1 & 2 \\
\hline & 74 & & & & & & \\
& 56 & & & & & & \\
3 & 1 & 180 & 165 & 120 & 2 & 2 & 4 \\
\hline
\end{tabular}




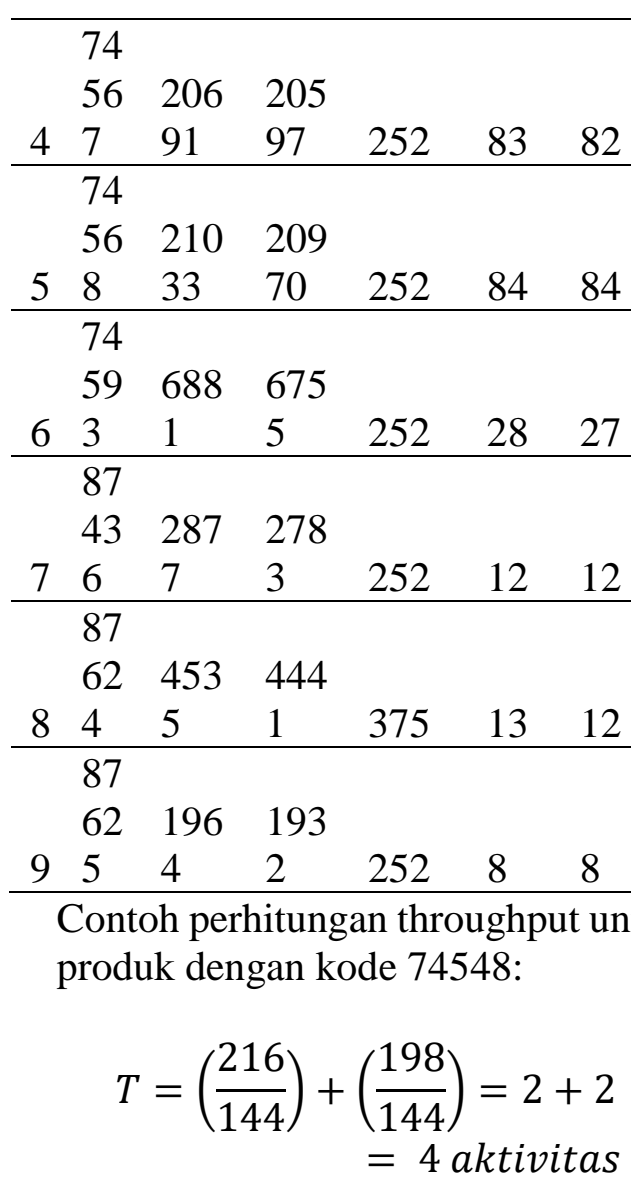

Perbandingan Throughput denngan Space Requirement (T/S) Pada Tabel 3 telah didapat kebutuhan ruang atau blok $\left(S_{j}\right)$ untuk tiap produk dan pada Tabel 4 dan Tabel 5 telah

Tabel 6. Perbandingan Throughput dengan Space Requirement (T/S) Zona A

\begin{tabular}{|c|c|c|c|c|c|c|}
\hline \multirow[b]{2}{*}{$\mathrm{K}$} & \multirow{3}{*}{$S$} & \multirow{2}{*}{\multicolumn{3}{|c|}{$\mathrm{T} / \mathrm{S}$}} & \multirow{2}{*}{\multicolumn{2}{|c|}{$\mathrm{T} / \mathrm{S}$}} \\
\hline & & & & & & \\
\hline $\mathrm{O}$ & & & $T$ & Ter & Kiri & \\
\hline d & $S$ & $\mathrm{~T}$ & K & ima & $\mathrm{m}$ & \\
\hline $\mathrm{Ne}$ & b & er & i & (A & (Ak & \\
\hline $\mathrm{O} P$ & I & i & $\mathrm{r}$ & kti & tivit & o \\
\hline$r$ & 0 & $\mathrm{~m}$ & i & vita & as/ & \\
\hline o & $\mathrm{k}$ & $\mathrm{a}$ & $\mathrm{m}$ & $\mathrm{s} / \mathrm{B}$ & Blo & \\
\hline d & & & & lok & k) & \\
\hline
\end{tabular}

87

162

\begin{tabular}{llllllll}
0 & 6 & 210 & 179 & 375 & 1 & 1 & 2 \\
\hline
\end{tabular}

Tabel 5. Throughput Tiap Jenis Produk Zona B 


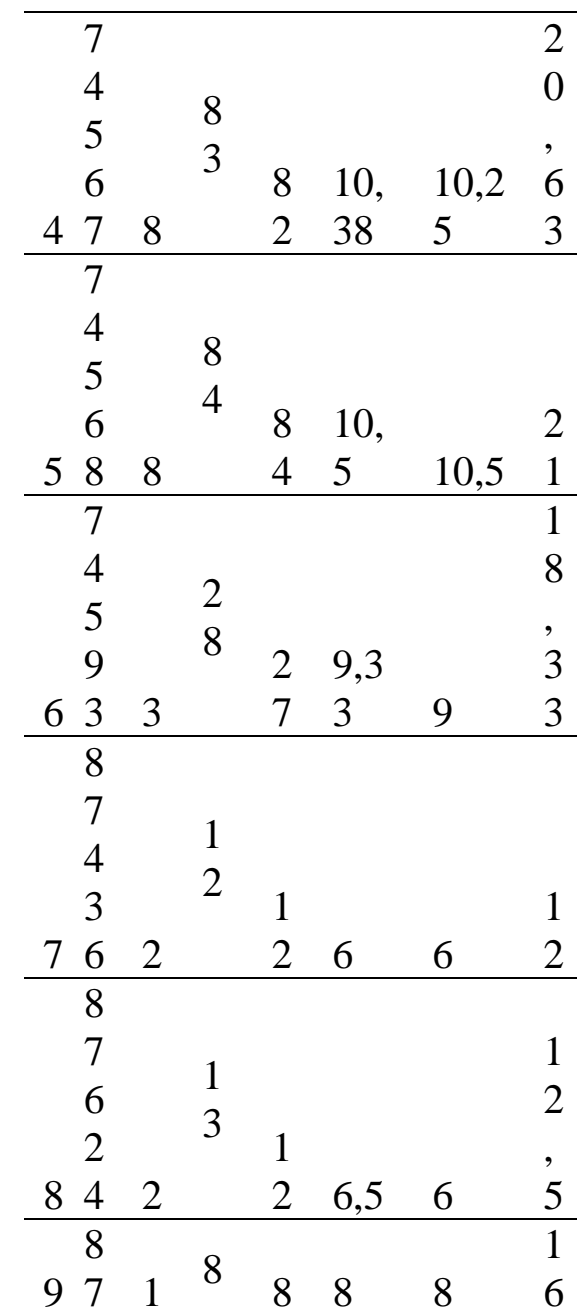

Peletakan produk dilakukan berdasarkan perbandingan throughput dengan space requirement (T/S), dimana T/S yang paling besar diletakkan pada blok yang paling pendek jarak tempuhmya. Berikut adalah perankingan produk berdasarkan T/S yang terbesar ke yang terkecil yang dapat dilihat pada Tabel 8.

\section{Perhitungan Jarak Perjalanan Tiap Blok Ke I/O Point}

Perhitungan jarak perjalanan tiap blok ke I/O dilakukan dengan menggunakan metode rectilinier distance, dimana jarak perjalanan merupakan jarak yang harus ditempuh material handling menuju

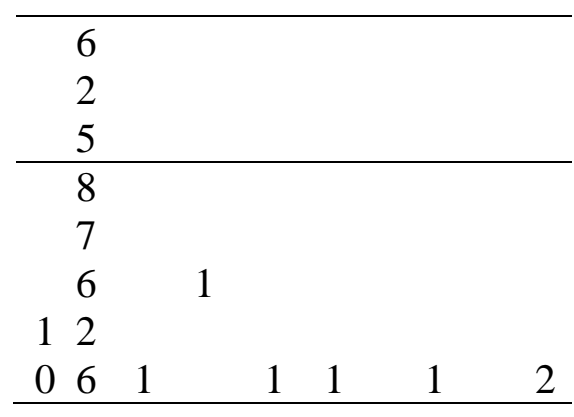

Tabel 7. Perbandingan Throughput dengan Space Requirement (T/S) Zona B

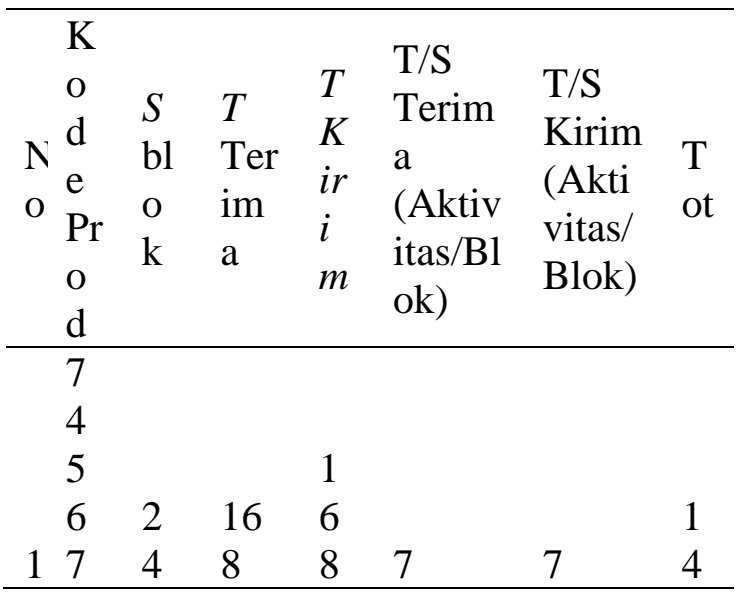

blok yang ada, dengan titik I/O sebagai titik awal perjalanannya. Jarak diukur sepanjang lintasan menggunakan garis tegak lurus (orthogonal) satu dengan yang lainnya. Ukuran blok zona A adalah $16,5 \mathrm{~m}$ untuk panjang dan 1,5 m untuk lebar, sedangkan untuk zona B adalah 10,5 m panjang dan lebar

Tabel 8. Perankingan Perbandingan $\mathrm{T} / \mathrm{S}$

\begin{tabular}{lll}
\hline No & $\begin{array}{l}\text { Kode } \\
\text { Produk }\end{array}$ & T/S \\
\hline 1 & 74568 & 21 \\
\hline 2 & $74567 \_1$ & 20,63 \\
\hline 3 & 74593 & 18,33 \\
\hline 4 & 87625 & 16 \\
\hline
\end{tabular}




\begin{tabular}{lll}
\hline 5 & $74567 \_2$ & 14 \\
\hline 6 & 87624 & 12,5 \\
\hline 7 & 87436 & 12 \\
\hline 8 & 74548 & 4 \\
\hline 9 & 74561 & 4 \\
\hline 10 & 74553 & 2 \\
\hline 11 & 87626 & 2 \\
\hline
\end{tabular}

1,5 m. Sebagai contoh untuk perhitungan blok AA_1 dari pintu masuk (I) dan pintu keluar (O) adalah:

$d=|41,25-0,75|+\mid 24,75-$

$0,75 \mid=64,50 \mathrm{~m}$

$d=|7,75-0,75|-\mid 24,75-$

$0,75 \mid=31 \mathrm{~m}$

\section{Penempatan Produk dan} Perhitungan Jarak Tempuh Total

Untuk dapat membandingkan jarak tempuh total material handling pada kondisi semula dengan kondisi usulan, maka dilakukan perhitungan untuk kedua kondisi tersebut.

\section{Perhitungan Kondisi Eksisting}

Pada kondisi eksisting penempatan produk tidak memiliki aturan baku sehingga produk bebas ditempatkan dimana saja. Kondisi inilah yang mengakibatkan jarak tempuh menjadi tidak dapat diprediksi dengan akurat. Sebagai contoh untuk perhitungan pada produk dengan kode 74568 adalah sebagai berikut:

Jarak Tempuh

$$
\begin{aligned}
& =(10,5 \times 476,63) \\
& +(10,5 \times 215,38) \\
& =7266 \mathrm{~m}
\end{aligned}
$$

Berdasarkan penempatan produk pada kondisi eksisting maka dapat dihitung jarak tempuh total sebesar 27038,1 m dengan layout penempatan produk awal dapat dilihat pada Gambar 3.

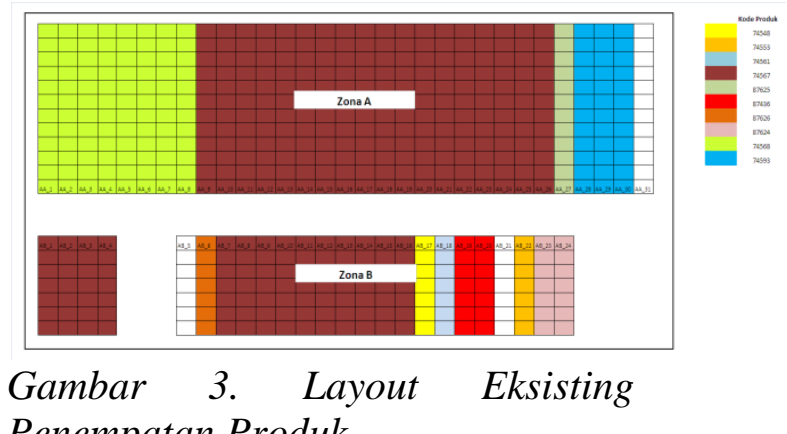

Penempatan Produk

\section{Perhitungan Usulan Perbaikan}

Penempatan produk pada layout usulan berdasarkan pada nilai $\mathrm{T} / \mathrm{S}$ terbesar yang ditempatkan pada jarak tempuh terpendek, sehingga terlebih dahulu harus dilakukan perankingan $\mathrm{T} / \mathrm{S}$ untuk setiap produk dari yang terbesar ke yang terkecil, serta menggunakan blok berdasarkan jarak tempuh yang terpendek. Perankingan T/S dapat dilihat pada Tabel 8 . Sebagai contoh perhitungan untuk produk 74567:

$$
\begin{aligned}
\text { Jarak Tempuh } & \\
& =(7 \times 978) \\
& +(7 \times 978) \\
& =13692 \mathrm{~m}
\end{aligned}
$$

Dari perbaikan layout usulan penempatan produk maka total jarak tempuh untuk memasukkan dan memindahkan seluruh jenis produk yang pada gudang adalah sebesar 23719,36 $\mathrm{m}$ dengan layout penempatan dapat dilihat pada Gambar 4. 


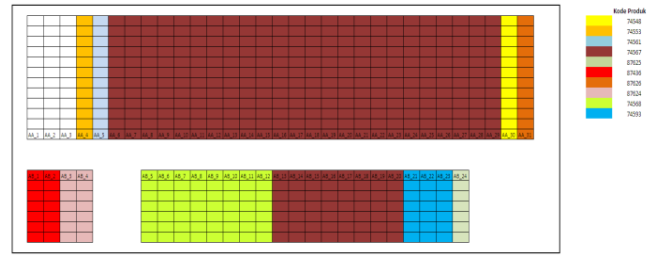

Gambar 4. Layout Usulan Penempatan Produk

\section{Perbandingan Jarak Tempuh Layout Eksisting dengan Layout Usulan}

Berdasarkan perhitungan jarak tempuh material handling layout awal dan layout usulan perbaikan, maka dilakukan perbandingan untuk mengetahui persentase penurunan jarak tempuh. Berikut perbandingan jarak tempuh layout awal dengan layout usulan yang dapat dilihat pada Tabel 9.

\section{Analisis}

Relayout di gudang sangat berperan dalam menjaga kelancaran operasi gudang dan dapat meningkatkan tingkat kepuasan pelanggan/konsumen. Dengan relayout penempatan barang di gudang secara efektif dan efesien, maka akan memberikan hasil yang optimum. Hasil dari relayout pada penelitian ini dapat meminimumkan jarak pemindahan produk sehingga dapat mempercepat proses pemindahan dan pada akhirnya produk dapat dikirim tepat pada waktunya. Tahap ini akan dilakukan analisis terhadap hasil yang diperoleh dari penyelesaian permasalahan tata letak mencakup penentuan lokasi penyimpanan pada gudang.

Tabel 9. Perbandingan Jarak Tempuh

Layout Eksisting dengan Layout Usulan

$\begin{array}{lllllll}\text { Layout } & \text { Jarak } & \text { Selisih } & \text { PersentaseUsulan } & 23719,36 & 3318,73 & 12,27 \\ & \text { Total } & \text { terhadap } & \text { penurunan } & & & \end{array}$

jarak \%

\section{Analisis Pemilihan Metode \\ Dedicated Storage Sebagai Usulan Perbaikan}

Metode dedicated storage digunakan pada penelitian ini sangat sesuai dengan permasalahan penempatan produk di Gudang PT XYZ, dimana perusahan ini menyimpan produk secara dedicated maksudnya satu blok untuk satu jenis produk yang sama baik ukuran maupun tanggal kadaluarsanya dan baru boleh terisi lagi apabila blok ini sudah kosong. Penyelesaian persoalan tata letak gudang dengan metode ini terdiri dari beberapa tahap. Tahap pertama adalah menentukan kebutuhan ruang (space requirement). Kebutuhan ruang diperoleh dari rata-rata penerimaan barang dalam satu periode dibagi kapasitas tempat penyimpanan. Berdasarkan hasil perhitungan, diperoleh kebutuhan ruang untuk tiap jenis produk yang ditempatkan pada zona A dan zona B. Tahap kedua yaitu menentukan throughput yang digunakan sebagai usulan perbaikan dalam penelitian ini. Pengukuran throughput dijadikan sebagai ukuran aktivitas aliran penyimpanan yang nantinya akan menghasilkan jarak perjalanan material handling minimum terhadap aktivitas pemindahan suatu beban dalam proses peletakkan produk. 


\section{Analisis Pengolahan Data}

Pengolahan data dalam penelitian dilakukan secara bertahap dan sistematis. Adapun analisis dari masing-masing tahap adalah sebagai berikut:

\section{Analisis Space Requirement (Kebutuhan Ruang)}

Space Requirement adalah produk yang ditempatkan pada lokasi yang lebih spesifik dan hanya satu jenis produk saja yang ditempatkan pada lokasi penyimpanan tersebut. Pada Gudang PT XYZ, perhitungan kebutuhan ruang digunakan untuk menentukan kapasitas penyimpanan pada blok penyimpanan yang tersedia untuk mengetahui apakah jumlah blok yang tercukupi atau tidak untuk menempatkan produk yang masuk ke gudang. Luas area, tinggi tumpukan maksimal dan jumlah produk dapat menentukan jumlah blok yang terpakai untuk satu jenis produk. Seperti yang dijelaskan sebelumnya, produk yang disimpan di Gudang PT XYZ disusun diatas pallet. Kapasitas pallet untuk menampung produk memiliki jumlah yang berbeda-beda.

Kapasitas blok di zona A dapat menampung 11 pallet yang ditumpuk sebanyak 3 tumpukan ke atas, sedangkan kapasitas blok di zona B dapat menampung 7 pallet yang ditumpuk sebanyak 3 tumpukan ke atas. Oleh karena itu, kebutuhan ruang berbeda-beda untuk masingmasing produk. Berdasarkan hasil perhitungan usulan, blok yang terpakai hanya 52 blok dari 55 blok yang tersedia di gudang. Blok yang tersisa tersebut bisa digunakan untuk menempatkan produk jika terjadi ledakan penerimaan produk untuk disimpan. Blok yang tersisa berada pada zona A, sedangkan blok di zona B dimaksimalkan pemanfaatannya karena memiliki jarak tempuh perjalanan yang lebih pendek. Pada kondisi eksisting, blok di zona A terisi penuh, sedangkan blok di zona B masih ada yang kosong.

\section{Analisis Throughput}

Throughput merupakan pengukuran aktivitas atau penyimpanan yang sifatnya dinamis yang menunjukkan aliran dalam penyimpanan. Pengukuran throughput digunakan sebagai ukuran jumlah aktivitas penyimpanan dan pengambilan produk dalam gudang. Pengukuran throughput ini menjadi salah satu proses dalam peletakan produk, dimana produk yang memiliki throughput paling tinggi ditempatkan pada blok yang paling dekat dengan pintu masuk dan pintu keluar untuk meminimalkan aktivitas material handling. Pada gudang ini, aktivitas forklift hanya dapat mengangkut 3 tumpukan pallet yang sudah terisi produk atau 252 box untuk kapasitas 1 pallet $=84$ box dan 375 box untuk kapasitas 1 pallet $=125$ box. Dari hasil perhitungan menunjukkan jumlah throughput sebanyak 801 yang artinya bahwa total aktivitas perjalanan pemindahan forklift untuk penyimpanan dan pengiriman selama 8 bulan.

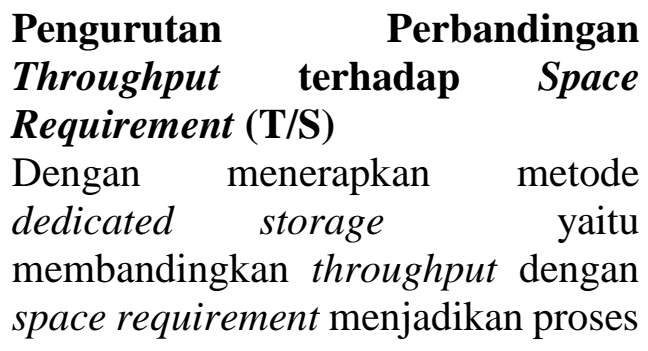


penyimpanan menjadi lebih baik dari sebelumnya, produk diatur dan diletakkan sesuai dengan jumlah aktivitas dan juga disesuaikan dengan kebutuhan ruang. Berdasarkan urutan perbandingan $\mathrm{T} / \mathrm{S}$, urutan tertinggi yaitu sebesar 21 aktivitas/blok pada produk 74568 yaitu Mizone Orang Lime dan terendah produk 87626 dengan 2 aktivitas /blok yaitu Levite Jambu Biji

\section{Analisis Pemilihan Metode Rectilinier Distance}

Setelah pengurutan T/S terbesar, kemudian blok ditempat kan pada blok dengan jarak terpendek. Penentuan blok yang berada pada jarak terpendek adalah dengan menggunakan metode rectilinier distance yaitu menghitung jarak perjalanan tiap blok ke I/O point. Jarak diukur sepanjang lintasan menggunakan garis tegak lurus satu dengan yang lainnya. Metode ini sangat tepat digunakan karena blok tidak memiliki jalan lintasan antara satu dengan yang lainnya kecuali antar zona, sehingga penyimpanan dan pengambilan produk hanya di depan blok saja.

\section{Analisis Penempatan Produk pada Kondisi Eksisting dan Usulan}

Penempatan produk di gudang PT.XYZ yang ada saat ini tidak memiliki aturan yang pasti. Produk yang datang harus ditempatkan pada blok yang kosong, sehingga terjadi penumpukan produk yang berlebihan. Keadaan ini akan menyebabkan kebutuhan ruang untuk penyimpanan menjadi lebih besar dan menimbulkan proses pencarian yang lebih lama.

Usulan penempatan produk di Gudang PT.XYZ menerapkan metode dedicated storage dengan cara merubah susunan penempatan produk. Penempatan produk berdasarkan urutan T/S terbesar pada blok yang memiliki jarak tempuh terpendek terhadap pintu masuk dan pintu keluar (I/O) point. Ketentuan ini adalah untuk memudahkan material handling pada proses penyimpanan dan pengambilan produk serta meminimasi jarak tempuh perjalanan material handling tersebut. Peletakkan produk pada blok hanya diperbolehkan untuk produk yang sama jenisnya dan tanggal kadaluarsanya sehingga meminimasi waktu pencarian karena gudang ini juga menerapkan sistem FIFO.

Berdasarkan penerapan metode ini, blok pada zona B lebih dimaksimalkan pemanfaatannya dibandingkan blok pada zona A. Produk yang disimpan di zona B berdasarkan usulan penempatan produk adalah Mizone Orange Lime, Mizone Apple Guava,Mizone Lychee Lemon, Mizone Fresh in JC Straw, Mizone Fresh in Crispy Apple, Levite Rasa Jeruk. Produk yang ditempatkan di zona A adalah Mizone Lychee Lemon,Aqua, Levite Rasa Jambu Biji, Aqua $1500 \mathrm{ml}$ dan Aqua $600 \mathrm{ml}$. Perubahan posisi ini juga mempertimbangkan kapasitas ruang karena perbedaan kapasitas antara zona A dan zona B.

\section{Analisis Perbandingan Jarak Perjalanan Total}

Setelah produk ditempatkan pada blok yang tersedia, maka dilakukan perbandingan jarak perjalana total, dimana untuk jarak perjalanan total pada usulan adalah 23719,36 m dan jarak ini memiliki selisi sebesar 3318,73 dengan kondisi eksisting 
yaitu sebesar 27038,1 m. Persentase penurunan jarak tempuh perjalanan dengan perubahan penempatan produk adalah sebesar 12,27 \%. Angka ini menunjukkan total jarak perjalanan yang diperlukan forklift di dalam gudang PT.XYZ lebih pendek dibandingkan kondisi eksisting dengan penurunan sebesar nilai tersebut untuk memasukkan dan mengirimkan seluruh produk di gudang dalam periode Januari sampai dengan Agustus 2015. Perubahan posisi penempatan produk di blokblok penyimpanan tidak mengganggu aktivitas proses pengiriman dan penyimpanan produk.

\section{Analisis Layout Penempatan Produk}

Perubahan dari hasil penempatan produk dengan menggunakan metode dedicated storage menghasilkan layout penyimpanan produk seperti pada Gambar 5. Produk ditempatkan pada blok berdasarkan pada tingkat aktivitas produk yang paling tinggi serta kebutuhan ruang simpan. Keunggulan dari penataan ulang ini adalah forklift yang digunakan sebagai alat material handling menempuh jarak lebih pendek. Lokasi blok yang memiliki jarak termpuh terbesar hanya dijadikan sebagai

\section{DAFTAR PUSTAKA}

Apple, J. (1990). Tata Letak Pabrik dan Pemindahan Bahan, Penerjemah: Nurhayati Mardiono.Bandung : Penerbit ITB.

Hadiguna, Rika dan Setiawan Heri.(2008).Tata Letak Pabrik.Yogyakarta:Andi Offset Permana,I (2014). Relayout Tata Letak Penempatan Gudang Produk tempat cadangan jika ada ledakan penerimaan barang. Berdasakan usulan, blok AA_1, AA_2 dan AA_3 tidak terisi produk, sementara blok di zona B terisi penuh. Blok-blok di zona B memiliki jarak tempuh lebih pendek dibandingkan blok-blok di zona A sehingga pemanfaatan ruang dimaksimalkan.

\section{KESIMPULAN}

Berdasarkan penelitian yang telah dilakukan dapat disimpulkan bahwa:

1. Usulan perbaikan tata letak penempatan produk di Gudang PT XYZ menerapkan metode dedicated storage.

2. Tata letak penempatan produk di Gudang PT.XYZ bertujuan untuk meminimasi jarak tempuh perjalanan forklift sebagai alat material handling di gudang tersebut.

3. Berdasarkan perhitungan, diperoleh totak jarak tempuh perjalanan forklift pada layout usulan sebesar 23719,36 m atau dengan persentase penurunan sebesar $12,27 \%$ dari layout eksisting.

Jadi Baja Tulangan Dengan Menggunakan Metode Dedicated Storage di PT.ABC. Skripsi.Teknik Industri.Universitas Sultan Ageng Tirtayasa.

Sugiharto.(2009).Analisa Manajemen Pergudangan pada PD Sinar Agung Jaya untuk Meningkatkan Efektifitas.Tesis S1, Universitas Bina Nusantara.Jakarta 
Sriyanto,Purwanggono Bambang dan Astuti Dessy T.(2009).Redesain Layout dan Prosedur Untuk Reduksi Waktu
Komponen.Jurnal

Tesis

S1, Universitas Dipenogoro, Semarang Vol 4, No2 